DOI: $10.14451 / 2.130 .24$

\title{
К ВОПРОСУ ЭФФЕКТИВНОСТИ НОВОВВЕДЕНИЙ В ИЗБИРАТЕЛЬНЫЕ ТЕХНОЛОГИИ
}

\author{
(c) 2019 Соколов Алексей Вячеславович \\ студент 4 курса, факультет «Политология и социология» \\ Финансовый университет при правительстве российской федерации, Россия, Москва
}

В работе проанализирована практика применения новых подходов в избирательных технологиях на примере выборов мэра Москвы в 2018 году.

Ключевые слова: Интересы избирателей, осведомленность кандидата об интересах избирателей, самовыдвижение кандидата, анализ результатов выборов мэра в 2013 году, новый имидж кандидата в мэры Москвы в 2018 году, предвыборные лозунги, моделируемый имидж кандидата.

Методологические подходы взаимосвязаны с теоретическими построениями в политологии, в силу этого процесс познания может стремиться к максимальной объективности через синтез инструментов познания. Данный подход имеет большое значение для познания процессов управления в политической системе.

Изучение политического поведения на основе предлагаемых методик важно для получения конечного политического знания, позволяющего на основе анализа данных формировать прогноз развития ситуации.

В современном обществе в большинстве развитых стран в основе государственного устройства лежит демократия. Демократия предполагает участие граждан в управлении государством. Формы участия могут иметь прямой и опосредованный характер. Прямая форма предполагает участие в выборах и референдумах любого уровня, начиная от муниципального заканчивая федеральным. Опосредованная форма участия предполагает артикуляцию интересов электората - граждан, избравших политика, и самого политика, представляющего интересы различных социальных групп.

Высокая конкуренция в представлении интересов граждан требует от кандидатов на занимаемый пост высокого уровня осведомленности о избирателях и их интересах, также от кандидата требуется наличие некоего опыта в государственном управлении или работе во властных структурах и наличие характеристик, которые могут ассоциировать кандидатов с политическим лидером. В связи с этим появилась необходимость выбрать основные принципы подготовки кандидатов разных уровней к борьбе за занимаемую должность.

Самовыдвиженцем на выборах мэра Москвы в 2018 году стал Сергей Собянин. Его конкурентами в борьбе за пост главы Москвы стали кандидат, выдвинутый от Коммунистической партии Российской Федерации де-юре, но де-факто бесспартийный Вадим Кумин. Кандидат от парламентской партии «Справедливая Россия» Илья Свиридов. Представителем от Либеральной Демократической партии России стал Михаил Дегтярев, участвовавший в избирательной кампании на пост мэра Москвы в 2013 году. Представителем от малочисленной и малоизвестной партии «Союз горожан» стал Михаил Балакин.

На выборах мэра Москвы 2018 года Собянин выдвинулся не от партии «Единая Россия», в которой он состоит в высшем совете, а пошел на выборы в качестве самовыдвиженца. Данное действие связано с падением рейтинга партии «Единая Россия» и негативной ассоциацией имиджа партии, С.С Собянин решил эту проблему таким образом, что он выдвинулся«не от партии, а от москвичей».

Исходя из данных о кандидатах на пост мэра Москвы, можно сделать вывод, что данные кандидаты не смогли составить реальную конкуренцию Сергею Собянину на выборах, их политический вес и совокупность достижений явно уступают достижениям действующего мэра.

Особенностью предвыборной кампании 2013 стала упорная борьба между Сергеем Собяниным и Алексеем Навальным, выразившаяся в преимуществе мэра в 24 процента. Действующий мэр Москвы Сергей Собянин получил менее $40 \%$ голосов в районе Сокол и в Гагаринском районе, причем в последнем он уступил оппозиционеру Алексею Навальному по числу голосов.

В 2018 г. действующий мэр Москвы получил как минимум 60\% голосов во всех районах Москвы. Особенно активно за него голосовали 
Таблица 1. Сравнительные результаты выборов

\begin{tabular}{|l|c|c|c|}
\hline \multicolumn{1}{|c|}{ Кандидаты и партии } & 2013 г, \% & 2018 г, \% & Динамика, \% \\
\hline Собянин С.С. & 51,37 & 70,07 & 18,7 \\
\hline Навальный А. & 27,24 & & \\
\hline КПРФ & 10,63 & 11,38 & 0,75 \\
\hline ЛДПР & 2,86 & 6,72 & 3,86 \\
\hline Справедливая Россия & 2,79 & 7,01 & 4,22 \\
\hline Яблоко & 3,51 & & \\
\hline Союз горожан & & 1,87 & \\
\hline
\end{tabular}

в районах Новой Москвы. Положительным результатом использования PR технологий выборной кампаний мэра Москвы в 2018 году явилась победа Сергея Семёновича Собянина с 70,07\% голосов, отдавших за него жителями Москвы.

Сравнительный анализ результатов выборов в 2013 году и в 2018 году в процентном соотношении приведен в таблице 1 .

Территория, на которой можно было проголосовать в сентябре 2018 года за своего кандидата, увеличилась. Это произошло за счёт того, что избирательные участки появились в Московской области и других смежных областях, таких как Тульская, Калужская, Ярославская, Владимирская. Всего было открыто 209 участков за пределами Москвы.

Сергей Семенович Собянин - действующий мэр Москвы, в связи с этим его можно отнести к категории политического лидера. Изначально образ Сергея Собянина трактовался экспертами в области имиджмейкинга как образ управленца. Проведенное исследование ВЦИОМ (Всероссийского центра исследования общественного мнения) показал, что Собянину для улучшения и оптимизации его имиджа нужно продемонстрировать свою любовь к Москве. «Демонстрация любви к Москве» может выражаться через знание истории города, проблемы районов, защиту памятников архитектуры.
Предвыборными лозунгами кандидата в мэра Москвы, действующего градоначальника Сергея Собянина стали «Москва еще безопаснее», «Москва еще прекраснее», «Москва еще зеленее», «Москва еще душевнее», «Москва еще чище», «Москва еще ближе» с добавлением «Мэр Собянин».

По мнению социологов, для наиболее благоприятного восприятия информации, мэру рекомендуется принимать решение о сохранении архитектурного здания или исторического квартала, хотя его снос принес бы городу доход. Данный PR ход нашел отражение в практике в 2018 году в ходе застройки завода «Серп и Молот» под угрозой сноса оказался мемориал погибшим во время Великой отечественной войны. Собянин заверил, «памятник будет сохранен», потому что это «святое». Данный поступок охарактеризовал мэра Москва как человечного и справедливого и положительно повлиял на его образ.

Идеальным имиджем Сергея Собянина возможно является тот образ, в котором его решения по градостроительной, социальной политике принимаются жителями города Москвы исключительно позитивно и не вызывают нареканий и разногласий. Моделируемый имидж Сергея Собянина - это образ успешного градоначальника.

\section{Библиографический список}

1. Конституция Российской Федерации. Ст. 32.

2. Федеральный закон от 29 мая 2019 года № 103-Ф3 «О проведении эксперимента по организации и осуществлению дистанционного электронного голосования на выборах депутатов Московской городской Думы седьмого созыва».

3. Баглай, М.В. Избирательная система и референдум Российской Федерации / М. В. Баглай // Конституционное право Российской Федерации. М.: Норма, 2006. С. 390-784.

4. Василенко И.А. Политология - М.: Юрайт, 2011-432 с.

5. Воробьев, Н. И., Никулин, В.В. Избирательное право и избирательный процесс в Российской Федерации / Н.И. Воробьев, В.В. Никулин. Тамбов: ТГТУ, 2005. с. 58.

6. Курс политологии: Учеб. для вузов/Авт. кол. А.Г. Грязнова, В.Т. Завьялов, Е.А. Звонова и др.; Фин. акад. при Прав-ве РФ.-2-е изд., доп.-М.: Инфра-М,2002.-460с. 